\title{
HIGH INTRASPECIFIC VARIATION IN THE DIET OF THE FRENCH ANGELFISH Pomacanthus paru IN THE SOUTH-WESTERN ATLANTIC
}

\author{
Daniela Batista $^{1,2}$, Guilherme Ramos da Silva Muricy ${ }^{l, *}$, Barbara Rustum Andréa ${ }^{3}$ and Roberto Campos Villaça ${ }^{4}$ \\ ${ }^{1}$ Universidade Federal do Rio de Janeiro - Museu Nacional, UFRJ \\ Departamento de Invertebrados \\ (Quinta da Boa Vista, s/n, São Cristóvão 20940-040, Rio de Janeiro, RJ, Brasil) \\ ${ }^{2}$ Departamento de Química da Pontifícia Universidade Católica do Rio de Janeiro \\ (Rua Marquês de São Vicente, 225, Prédio Cardial Leme, Bloco Leopoldo Hainberger S.J., 22453-900 Rio de Janeiro, RJ - Brasil) \\ ${ }^{3}$ Colégio A. Liessin \\ (Estrada do Joá, 3597, 22261-020 Rio de Janeiro, RJ, Brasil) \\ ${ }^{4}$ Universidade Federal Fluminense - Departamento de Biologia Marinha \\ (P.O. Box 100.644, 24001-970, Niterói, RJ, Brasil) \\ *Corresponding author: muricy@mn.ufrj.br
}

Descriptors: Angelfish, Diet, Porifera, Algae, South-eastern Brazil.

Descritores: Peixe-anjo, Dieta, Porifera, Algas, Sudeste do Brasil.

Grazing by reef fishes is among the most important biotic factors controlling the structure of benthic communities in coral reefs and tropical rocky shores (e.g., HIXON, 1983). Exclusion experiments have widely demonstrated that fish grazing is a key factor determining algal abundance, with direct and indirect effects on corals and other competing benthic organisms (e.g., SAMMARCO, 1983; LEWIS, 1986; HUGUES et al., 2007). Grazer exclusion reduces the resilience of coral reefs in face of disturbances such as hurricanes, bleaching events, and climate change (HUGUES et al., 2007; MUMBY, 2009). Underwater observations and palatability, caging and transplantation experiments indicate that grazing by reef fish also has strong influence on the abundance, distribution and shape of sponges (PAWLIK, 1998; WULFF, 2000; RUZICKA; GLEASON, 2009; LOH; PAWLIK, 2009).

Angelfishes (family Pomacanthidae) are very common and conspicuous reef fishes with a circum-global distribution on tropical and warm temperate reefs. Pomacanthids feed mainly on the structurally resilient and firmly attached benthic prey items avoided by most predators (KONOW; BELLWOOD, 2005). Sponges are the dominant item in the diet of several species of the genera Holacanthus and Pomacanthus, which are therefore often called spongivorous, while algae are usually a secondary item (e.g., RANDALL; HARTMAN, 1968; HOURIGAN et al., 1989; WULFF, 1994; VERDÍN et al., 2010). The diet of adult Western Atlantic angelfishes has only been studied in a few localities in the Caribbean (RANDALL; HARTMAN, 1968; HOURIGAN et al., 1989; WULFF, 1994; DUNLAP; PAWLIK, 1996; PAWLIK, 1998; SWEARINGEN; PAWLIK, 1998). In the South-western Atlantic only juveniles have been studied (SAZIMA et al., 1999; ANDRÉA et al., 2007). Francini-Filho and Moura (2010) observed the feeding of adult Pomacanthus arcuatus and $P$. paru on the zoanthid Palythoa caribaeorum in Abrolhos, without giving any attention to other items of their diet. Ferreira et al. (2004) and Ruzicka and Gleason (2008) stressed the need to determine the extent of geographical variation in diet composition of spongivorous reef fishes, including angelfishes, to better understand the latitudinal variation of predation and herbivory intensity on Western Atlantic coral reefs. However, virtually nothing is yet known about the feeding habits of South-western Atlantic adult angelfishes.

The French angelfish Pomacanthus paru inhabits coral reefs and rocky shores from Florida (USA) to Santa Catarina State (Southern Brazil) (e.g., RANDALL; HARTMAN, 1968; FERREIRA et al., 2004). Due to its high abundance, colour pattern and large size, it is one of the most conspicuous and recognizable species of the family Pomacanthidae in the Caribbean (DELOACH, 1999). In Brazil P. paru is the most abundant angelfish and shows a patchy distribution, with peaks of abundance in Parcel Manoel Luís $\left(0.52^{\circ} \mathrm{S}\right)$, Abrolhos $\left(17.20^{\circ} \mathrm{S}\right)$, and Arraial do Cabo $\left(23.0^{\circ} \mathrm{S}\right)$ (FERREIRA et al., 2004). In the South-western Atlantic, juveniles of $P$. paru have been reported as fish cleaners in Abrolhos, North-eastern Brazilian coast (SAZIMA et al., 1999), but a great diversity of sponges was also detected in their gut contents in Salvador, Bahia State (ANDRÉA et al., 2007). No data are available on the diet composition of adult $P$. paru or any other angelfish on the Brazilian coast, which represents approximately half of the latitudinal distribution of the most common Western Atlantic angelfishes. Here we investigated the 
intraspecific variation in diet composition of Pomacanthus paru by means of gut content analysis in three localities along the Brazilian coast.

Fieldwork was conducted from January to July 2005 at Atol das Rocas $\left(3^{\circ} 52^{\prime} \mathrm{S}-33^{\circ} 42^{\prime} \mathrm{W}\right)$, Abrolhos Archipelago (17 $\left.58^{\prime} \mathrm{S}-38^{\circ} 42^{\prime} \mathrm{W}\right)$ and Ilha Grande $\quad\left(23^{\circ} 04 \mathrm{~S}-44^{\circ} 19^{\prime} \mathrm{W}\right) \quad$ (Fig. 1). Detailed descriptions of these sites can be found elsewhere (KIKUCHI; LEÃO, 1997; VILLAÇA; PITOMBO, 1997; MORAES et al., 2003; CREED; OLIVEIRA, 2007). Samples were collected in two large tidal pools at Atol das Rocas (Barretinha and Barreta Falsa), one fringing reef in Abrolhos (Portinho Sul), and one rocky coast on Ilha Grande (Lagoa Verde) (Fig. 1).

Fifteen specimens of the French angelfish with standard length varying from $33-46 \mathrm{~cm}$ were sampled through spear fishing ( $\mathrm{n}=5$ per locality). Stomachs were removed and fixed in $70 \%$ ethanol. The fish were fixed in $4 \%$ formaldehyde and deposited at the fish collection of Museu Nacional, Universidade Federal do Rio de Janeiro, Brazil. The guts were dissected and stomach contents were separated under a stereomicroscope and fixed in $70 \%$ ethanol; intestinal contents were not included in the analysis because they were too degraded for identification. Algae were identified under a stereomicroscope; sponges were dehydrated and placed in paraffin to prepare transversal sections for identification under a light microscope. Only fragments that could be sectioned were identified; isolated spicules and the smallest (approximately $<1 \mathrm{~mm}^{3}$ ) or highly digested fragments, which could not be identified with certainty, were considered "undetermined". Other invertebrates (tunicates and cnidarians) were identified only to higher taxonomic levels. The percentages (in volume) of sponges and algae per stomach were determined on a grid under a stereomicroscope. One-way ANOVA was used to compare the percentages of both sponges and algae in angelfish diet among the three sites. Data were examined a priori for normality and homoscedasticity using Kolmogorov-Smirnov and Levene Tests, respectively, and the post-hoc Tuckey test was used to determine which sites were significantly different (ZAR, 1999). All statistics were calculated using Vassar online software (http://faculty.vassar.edu/lowry//VassarStats.html).

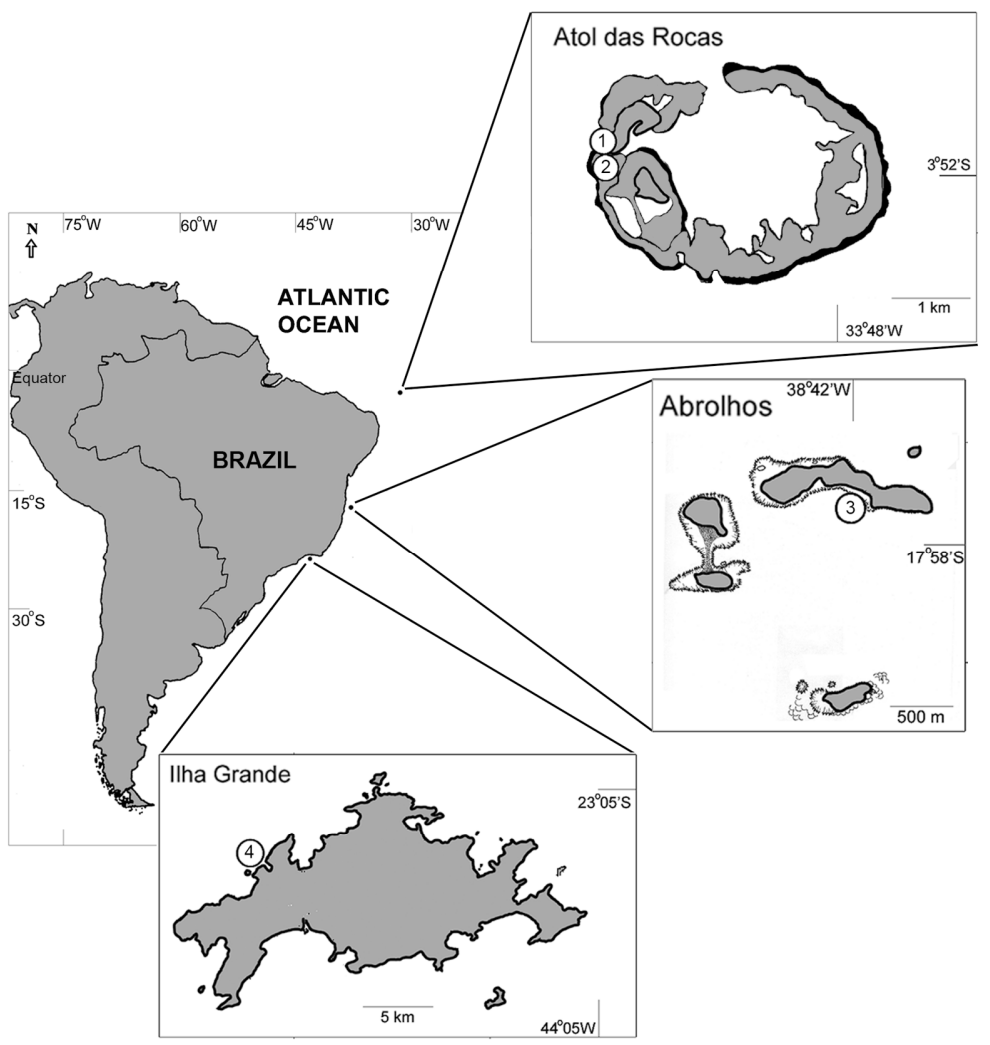

Fig. 1. Location of the collection sites (encircled numbers) in the three localities studied: Atol das Rocas (1, Barretinha; 2, Barreta Falsa Pool); Abrolhos (3, Portinho Sul); and Ilha Grande (4, Lagoa Verde). 
Gut length data were obtained from freshly killed specimens right after collection. Viscera were excised from each specimen and extended to measure the gut from the posterior-most point of the stomach to the vent. Gut lengths were compared with total lengths to calculate the relative gut length index.

Considering the three sites altogether, algae represented $63.2 \pm 32.1 \%$ of the total gut contents of $P$. paru in Brazil, followed by sponges $(31.5 \pm 32.1 \%)$, undetermined material $(4.0 \pm 7.4 \%)$, tunicates $(0.9 \pm 1.3 \%)$ and cnidarians $(0.4 \pm 1.1 \%)$. A total of 36 sponge species (Table 1) and 26 species of algae (Table 2) were found in gut contents. Intraspecific variation of diet contents was high: the ratio of algae to sponges in individual fish varied from 0.05 to 23.75 (Fig. 2). Algae composed 5-95\% of the gut contents in each individual examined, and 11 fish (73.3\%) had $50 \%$ or more of their gut content composed of algae. The percentages of algae and sponges varied significantly among the different locations: algae were the main food item at Atol das Rocas and Abrolhos (91.0 $\pm 4.4 \%$ and $70.0 \pm 24.2 \%$, respectively [mean $\pm \mathrm{SD}$ ]) but comprised only $28.6 \pm 22.1 \%$ of the diet on Ilha Grande (ANOVA, d.f. $=2, F=13.83, p=0.000767$ ). In contrast, sponges were the main group consumed by $P$. paru on Ilha Grande $(69.8 \pm 22.0 \%$ of gut contents), but were significantly less predated on Abrolhos $(18.8 \pm 16.2 \%)$ and Atol das Rocas (6.0 $\pm 2.2 \%$ ) (ANOVA, d.f. $=2$, $\mathrm{F}=22.73, \mathrm{p}<0.0001$; Fig. 3). The relative gut length index was $5.27 \pm 0.96(n=15)$.

All algae and most sponge species were eaten at only a single site each. Tedania ignis, Spirastrella hartmani, Aaptos aff. aaptos and Halichondria sp. were eaten at two sites, and Chondrilla aff. nucula was the only species eaten in all three localities (Table 1). These results indicate a high geographical variation in the qualitative composition of the diet of $P$. paru that is probably related to the limited distribution of most prey species, which may be absent or rare in some areas. Although some of the above-mentioned species are among the most abundant and widely distributed sponges in Brazil, our qualitative data do not allow us to determine feeding preferences of $P$. paru for any prey species. It is remarkable, however, that Tedania ignis, Chondrilla nucula and species of Spirastrella (S. coccinea, S. hartmani, Spirastrella sp.) were also eaten by adult $P$. paru in the Caribbean and by juveniles in Salvador, Brazil (RANDALL; HARTMAN, 1968; WULFF, 1994; PAWLIK, 1998; SWEARINGEN; PAWLIK, 1998; ANDRÉA et al., 2007). This may indicate that $P$. paru has a preference for these species and actively searches for them, but experimental evidence is needed to test this hypothesis.
Table 1. Presence of sponges in gut contents of Pomacanthus paru in three localities in Brazil.

\begin{tabular}{|c|c|c|c|}
\hline Sponges & $\begin{array}{c}\text { Atol das } \\
\text { Rocas }\end{array}$ & Abrolhos & $\begin{array}{c}\text { Ilha } \\
\text { Grande }\end{array}$ \\
\hline $\begin{array}{l}\text { Chondrilla aff. } \\
\text { nucula }\end{array}$ & + & + & + \\
\hline Aaptos aff. aaptos & + & + & \\
\hline $\begin{array}{l}\text { Spirastrella } \\
\text { hartmani }\end{array}$ & + & + & \\
\hline Acervochalina sp. 4 & + & & \\
\hline $\begin{array}{l}\text { Amphimedon aff. } \\
\text { compressa }\end{array}$ & + & & \\
\hline $\begin{array}{l}\text { Clionaidae } \\
\text { unidentified }\end{array}$ & + & & \\
\hline Plakortis & + & & \\
\hline
\end{tabular}

microrhabdifera

Halichondria sp.

Tedania ignis

Acervochalina sp. 2

Acervochalina sp. 3

Chalinidae

unidentified 2

Cliona varians

Niphatidae

unidentified

Petrosiidae

unidentified

Suberitidae

unidentified 2

Tedania sp.

Tethya sp.

Thorectidae

unidentified

Spongiidae

unidentified

Acervochalina sp. 1

Amphimedon cf.

viridis

Callyspongiidae

unidentified

Chalinidae

unidentified 1

Clathria

Microciona sp.)

Desmapsamma

anchorata

Dragmacidon

reticulatum

Dragmacidon sp.

Dysidea janiae

cf. Leucandra sp.

Mycale sp.

Mycale cf. angulosa

Mycale

$+$

$+$

microsigmatosa

Polymastia

janereinsis

Suberitidae

unidentified 1

Terpios cf. fugax 


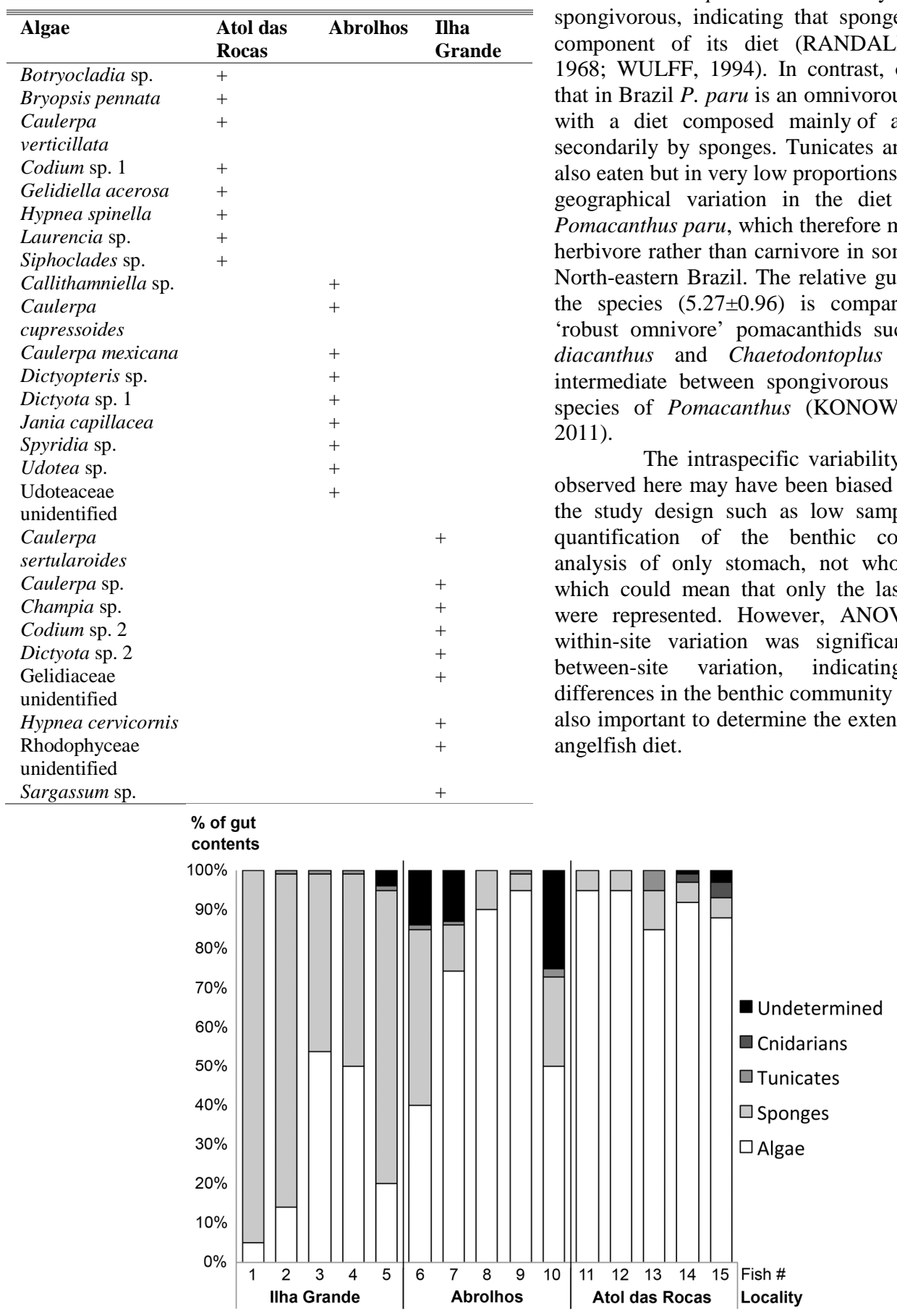

Fig. 2. Percentages (in volume) of taxonomic groups and undetermined material in gut contents of 15 adult specimens of Pomacanthus paru (numbered \# 1-15) from three localities in Brazil: Fish \# 1-5, Ilha Grande; \# 6-10, Abrolhos Archipelago; \# 11-15, Atol das Rocas.
Table 2. Presence of algae in gut contents of Pomacanthus paru in three localities in Brazil.

In the Caribbean, the French Angelfish Pomacanthus paru is usually classified as spongivorous, indicating that sponges are the major of its diet (RANDALL; HARTMAN, , our resuls show the the species $(5.27 \pm 0.96)$ is comparable to that of 'robust omnivore' pomacanthids such as Pygoplites duboulayi, and species of Pomacanthus (KONOW; BELLWOOD, The intraspecific variability of $P$. paru diet quantification of the benthic communities, and analysis of only stomach, not whole gut contents, A showed that between-site variation, indicating that spatial differences in the benthic community between sites are also important to determine the extent of variability in Rhodophyceae $++\quad$ angelfish diet. 


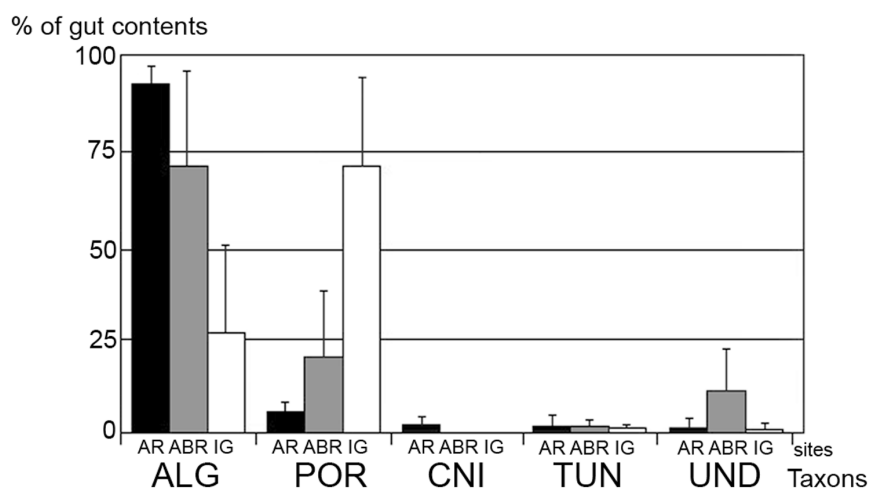

Fig. 3. Percentages (average and SD) of taxonomic groups and undetermined material in gut contents of Pomacanthus paru in three sites in Brazil: Atol das Rocas (AR, black bars), Abrolhos Archipelago (ABR, grey bars) and Ilha Grande (IG, white bars). Taxons: ALG, algae; POR, poriferans; CNI, cnidarians; TUN, tunicates; UND, undetermined material.

Intraspecific variation in diet composition was also found in the closely related species Pomacanthus zonipectus and Holacanthus passer from the Eastern Pacific, which may behave as omnivorous with adaptations to herbivory (PÉREZ-ESPAÑA; ABITIA-CÁRDENAS, 1996) or as spongivorous (VERDÍN et al., 2010). This variation appears to be related to the differences in local food availability (VERDÍN et al., 2010). In Brazil, algae are the most abundant organisms on the shallow reefs of Atol das Rocas and Abrolhos (KIKUCHI; LEÃO, 1997; MORAES et al., 2003; VILLAÇA; PITOMBO, 1997), where they are the main food of the French angelfish. The low similarity in qualitative composition of the diet between the three sites further supports the idea that diet composition is correlated to the composition of the benthic community, which varies in different localities. However, the adequate quantitative data on the structure of the benthic communities at each site needed to test this hypothesis is still lacking. An omnivorous strategy allows the grazer to change its diet according to local prey availability, but a balance between animal and vegetal food sources is often necessary to fulfil the dietary requirements of omnivorous fishes (e.g., RAUBENHEIMER et al., 2005). Furthermore, the high within-site variation in diet contents on Abrolhos and Ilha Grande indicates that other factors beyond food availability (e.g., age, sex, genetic variation, individual behaviour; e.g., SINGER; BERNAYS, 2003) are also important in determining angelfish diet and its variations.

\section{ACKNOWLEDGEMENTS}

We are grateful to Sergio Cabral, Tiago Candelot, Robson Aragão and Pablo Rodrigues for help in the fieldwork, to IBAMA for collection permits, and to Renato C. Pereira and Carlos E. L. Ferreira for useful discussions. The advice of two anonymous reviewers greatly improved the manuscript. Project Aware (PADI), FAPERJ, CNPq, CAPES and CENPES-PETROBRAS provided financial support.

\section{REFERENCES}

ANDRÉA, B. R.; BATISTA, D.; SAMPAIO, C. L. S.; MURICY, G. Spongivory by juvenile angelfish (Pomacanthidae) in Salvador, Bahia State, Brazil. In: CUSTODIO, M. R.; LÔBO-HAJDU, G.; HAJDU, E.; MURICY, G. (Ed.). Porifera Research: Biodiversity, innovation and sustainability. Rio de Janeiro: Museu Nacional, 2007. p. 131-137. Série Livros 29.

CREED, J. C.; OLIVEIRA, A. E. S. Capítulo 3. Índice geográfico e descrição dos locais de estudo. In: CREED, J. C.; PIRES, D. O.; FIGUEIREDO, M. A. O. (Eds.). Biodiversidade Marinha da Baía da Ilha Grande. Brasília: MMA, 2007. p. 75-108.

DELOACH, N. Reef fish behavior - Florida, Caribbean, Bahamas. Jacksonville: New World Publications, 1999. $359 \mathrm{p}$.

DUNLAP, M.; PAWLIK, J. R. Video-monitored predation of Caribbean reef fishes on an array of mangrove and reef sponges. Mar. Biol., v. 126, pp. 117-123, 1996.

FERREIRA, C. E. L.; FLOETER, S. R.; GASPARINI, J. L., FERREIRA, B. P., JOYEUX, J. C. Trophic structure patterns of Brazilian reef fishes: a latitudinal comparison. J. Biogeogr., v. 31, p. 1093-1106, 2004.

FRANCINI-FILHO, R. B.; MOURA, R. L. Predation on the toxic zoanthid Palythoa caribaeorum by reef fishes in the Abrolhos Bank, Eastern Brazil. Braz. J. Oceanogr., v. 58, p. $77-79,2010$

HIXON, M. A. Effects of reef fish on corals and algae. In: BIRKELAND, C. (Ed.). Life and Death of Coral Reefs. London: Chapman \& Hall, 1983. p. 230-246. 
HOURIGAN, T. F.; STANTION, F. G.; MOTTA, P. J.; KELLEY, C. D.; CARLSON, B. The feeding ecology of three species of Caribbean angelfishes. Environ. Biol. Fishes, v. 24, p. 105-116, 1989.

HUGHES, T. P.; RODRIGUES, M. J.; BELLWOOD, D. R.; CECCARELLI, D.; HOEGH-GULDBERG, O.; MCCOOK, L.; MOLTSCHANIWSKYJ, N.; PRATCHETT, M. S.; STENECK, R. S.; WILLIS, B. Phase shifts, herbivory, and the resilience of coral reefs to climate change. Curr. Biol., v. 17, p. 360-365, 2007.

KIKUCHI, R. K. P.; LEÃO, Z. M. A. N. Rocas (Southwestern Equatorial Atlantic, Brazil): an atoll built primarily by coralline algae. INTERN. CORAL REEF SYMP.,8, 1996, Panama City. Proceedings...v. 1, p. 731-736, 1997.

KONOW, N.; BELLWOOD, D. R. Evolution of high trophic diversity based on limited functional disparity in the feeding apparatus of marine angelfishes (f. Pomacanthidae). PLoS One, v. 6, n. 9. e24113. doi:101371/journal.pone.00244113.2001

KONOW, N.; BELLWOOD, D. R. Prey capture in Pomacanthus semicirculatus (Teleostei, Pomacanthidae): functional implication of intramandibular joints in marine angelfishes. J. Exp. Biol., v. 208, p. 1421-1433, 2005.

LEWIS, S. M. The role of herbivorous fishes in the organization of a Caribbean reef community. Ecol. Monogr., v. 56, p. 183-200, 1986.

LOH. T.-L.; PAWLIK, J. Bitten down to size: Fish predation determines growth form of the Caribbean coral reef sponge Mycale laevis. J. Exp. Mar. Biol. Ecol., v. 374, p. 45-50, 2009.

MORAES, F. C.; VILANOVA, E. P.; MURICY, G Distribuição das esponjas (Porifera) na Reserva Biológica do Atol das Rocas, Nordeste do Brasil. Arq. Mus. Nac., v. 61, p. 13-22, 2003.

MUMBY, P. J. Herbivory versus corallivory: are parrotfish good or bad for Caribbean coral reefs? Coral Reefs, v. 28, p. 683-690, 2009.

PAWLIK, J. R. Coral reef sponges: Do predatory fishes affect their distribution? Limnol. Oceanogr., v. 43, n. 6, p. 1396-1399, 1998.

PÉREZ-ESPAÑA, H.; ABITIA-CÁRDENAS, L.A. Description of the digestive tract and feeding habits of the king angelfish and the Cortes angelfish. J. Fish Biol., v. 48, p. 807-817, 1996.

RANDALL, J. E.; HARTMAN, W. D. Sponge-feeding fishes of the West Indies. Mar. Biol., v. 1, p. 216-225, 1968.
RAUBENHEIMER, D.; ZEMKE-WHITE, W. L.; PHILLIPS, R. J.; CLEMENTS, K. D. Algal macronutrients and food selection by the omnivorous marine fish Girella tricuspidata. Ecology, v. 86, p. 2601-2610, 2005.

RUZICKA, R.; GLEASON, D. F. Latitudinal variation in spongivorous fishes and effectiveness of sponge chemical defenses. Oecologia, v. 154, p. 785-794, 2008.

RUZICKA; GLEASON, 2009. Sponge community structure and anti-predator defenses on temperate reefs of the South Atlantic Bight. J. Exp. Mar. Biol. Ecol., v. 380, p. 36-46, 2009.

SAMMARCO, P. W. Effects of fish grazing and damselfish territoriality on coral reef algae. I. Algal community structure. Mar. Ecol. Progr. Ser., v. 13, p. 1-14, 1983.

SAZIMA, I.; MOURA, R. L.; SAZIMA, C. Cleaning activity of juvenile angelfish, Pomacanthus paru, on the reefs of the Abrolhos Archipelago, western South Atlantic. Environ. Biol. Fishes, v. 56, p. 399-407, 1999.

SINGER, M.; BERNAYS, E. A. Understanding omnivory needs a behavioral perspective. Ecology, v. 84, n. 10, p. 2532-2537, 2003

SWEARINGEN, D. C.; PAWLIK, J. R.. Variability in the chemical defense of the sponge Chondrilla nucula against predatory reef fishes. Mar. Biol., v. 131, p. 619617, 1998.

VERDÍN, P.; CARBALlO, J. L.; CAMACHO, M. L. A qualitative assessment of sponge-feeding organisms from the Mexican Pacific coast. Open Mar. Biol. J., v. 4, p. 39-46. 2010.

VILLAÇA, R.; PITOMBO, F. Benthic communities of shallow-water reefs of Abrolhos, Brazil. Rev. Bras. Oceanogr., v. 45, p. 35-43, 1997.

WULFF, J. L. Sponge feeding by Caribbean angelfishes, trunkfishes and filefishes. In: VAN SOEST, R. W. M.; VAN KEMPEN, T. M. G.; BRAEKMAN, J. C. (Eds.). Sponges in time and space. Rotterdam: Balkema, 1994. p. 265-271.

WULFF, J. Sponge predators may determine differences in sponge fauna between two sets of mangrove cays, Belize barrier reef. Atoll Res. Bull., v. 477, p. 251-263, 2000.

ZAR, J. H. Biostatistical analysis. 4th Edition. Upper Saddle River, NJ: Prentice-Hall, 1999. 663 p.

(Manuscript received 05 September 2011; revised 25 May 2012; accepted 05 June 2012) 